\title{
Theoretical Considerations Regarding the Thione-thiol Tautomerism in 2-(5-mercapto-1,3,4-thiadiazol-2-ylthio)acetic Acid
}

\author{
Raluca Pop, ${ }^{1, *}$ Maria Ilici, ${ }^{2, *}$ Mihaiela Andoni, ${ }^{1}$ Vasile N. Bercean, ${ }^{2}$ \\ Cornelia Muntean, ${ }^{2}$ Monica M. Venter, ${ }^{3}$ and Ilie Julean ${ }^{2}$ \\ ${ }^{1}$ University of Medicine and Pharmacy “Victor Babeş" Timisoara, Faculty of Pharmacy, Eftimie Murgu Square 2, \\ 300041 Timişoara, Romania \\ ${ }^{2}$ University POLITEHNICA Timisoara, Faculty of Industrial Chemistry and Environmental Engineering, \\ 300006 Timisoara, Romania \\ ${ }^{3}$ Babes-Bolyai" University, Faculty of Chemistry and Chemical Engineering, 11 Arany Janos Str., \\ 400028 Cluj-Napoca, Romania. \\ *Corresponding author: E-mail: ralucapop24@gmail.com; ilici2011@gmail.com
}

Received: 24-04-2014

\begin{abstract}
The acidity constants $\mathrm{K}_{\mathrm{a} 1}$ and $\mathrm{K}_{\mathrm{a} 2}$ of 2-(5-mercapto-1,3,4-thiadiazol-2-ylthio)acetic acid have been determined both by experimental and theoretical methods. $\mathrm{pK}_{\mathrm{a}}$ computations at $\mathrm{B} 3 \mathrm{LYP} / 6-311+\mathrm{G}(\mathrm{d}, \mathrm{p})$ level of theory were carried out for the two tautomeric forms, thiol and thione, of the above-mentioned acid. Comparisons between the experimental and theoretical values led to the establishing of the most stable tautomer of 2-(5-mercapto-1,3,4-thiadiazol-2-ylthio)acetic acid in aqueous solution. Also, a DFT study regarding the reactivity, aromaticity and population analysis of the two tautomers has been performed.
\end{abstract}

Keywords: thiadiazole, $\mathrm{pK}_{\mathrm{a}}$, thiol-thione tautomerism, theoretical computations, DFT.

\section{Introduction}

Together with the other 5-membered heterocycles, thiadiazoles have gained an increased popularity during the last decades. Their importance is due to their versatility and their biologic activity as antitumor, antifungal and antiviral agents. ${ }^{1,2}$ The presence of the sulfur atom within the cyclic structure confers them, compared to the 5-membered nitrogen heterocycles, an improved liposolubility and better penetration of the cellular membranes. ${ }^{2}$ Also, the 5-imino-1,2,4-thiadiazole derivatives are found to be inhibitors of glycogen synthase kinase 3 (GSK3), a protein kinase with active role in diabetes, cancer and Alzheimer's disease. ${ }^{3,4}$

In the case of heterocyclic moieties that show biologic activity and where the possibility of the co-existence of two tautomeric forms appears, it becomes very important to determine the most stable tautomer. Nowadays, computational chemistry techniques allow the prediction of the tautomeric behavior prior to the experimental studies. ${ }^{5}$ There are numerous papers that where published in the last years regarding theoretical studies of the thiolthione, ${ }^{6-9}$ keto-enol, ${ }^{10}$ formamide-formamidic acid, ${ }^{11}$ nucleic acid bases, ${ }^{12,13}$ heterocyclic rings -pyrazoles, triazoles ${ }^{14-17}$ tautomerism.

The 5-membered mercapto-aza heterocyclic derivatives (like Bismuthiol - dimercaptothiadiazole) were used with good results for the preparation of new metal complexes. ${ }^{18}$ Within our research group, there has been reported the obtaining of various metal complexes of the dimercaptothiadiazole derivatives ${ }^{18-19}$ A derivative of 1,3,4thiadiazol-2-yl-thioacetic acid, which can exist both in thiol (2-(5-mercapto-1,3,4-thiadiazol-2-ylthio)acetic acid) or thione (2-(5-thioxo-4,5-dihydro-1,3,4-thiadiazol-2ylthio)acetic acid) form, has been used for the preparation of metal complexes with various transitional metals. ${ }^{19}$ 
Previous studies of our research group have highlighted two possible tautomeric forms: thiol $(5 \mathrm{SH}, \mathbf{I a})$ and thione $(5 \mathrm{~S}, \mathbf{I b}) .{ }^{19,20}$ In this regard, the $\mathrm{pK}_{\mathrm{a}}$ values for the two deprotonation stages of each tautomer may offer valuable data regarding the stability of both tautomer species in aqueous solution.

The present study deals with the evaluation, both by theoretical and experimental methods, of the $\mathrm{pK}_{\mathrm{a}}$ of 2-(5mercapto-1,3,4-thiadiazol-2-ylthio)acetic acid. This way, an estimation of the $\mathrm{pK}_{\mathrm{a}}$ values by theoretical means -using both thermodynamic cycles ${ }^{21-24}$ and isodesmic reactions $^{25}$ - may also result in clarifying the issues regarding the dominant tautomer in aqueous solution.

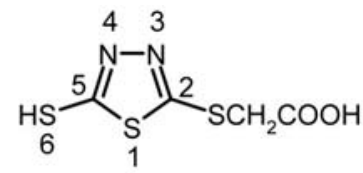

Ia

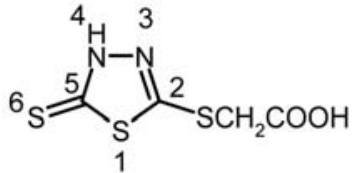

Ib
Scheme 1. Tautomeric structures of 2-(5-mercapto-1,3,4-thiadiazol-2-ylthio)acetic acid $\mathbf{I}\left(\mathrm{C}_{4} \mathrm{H}_{4} \mathrm{~S}_{3} \mathrm{~N}_{2} \mathrm{O}_{2}\right)(\mathbf{I a}$ - thiol form; $\mathbf{I b}$ - thione form).

In order to estimate the theoretical $\mathrm{pK}_{\mathrm{a}}$ value of the 2-(5-mercapto-1,3,4-thiadiazol-2-ylthio)acetic acid, two thermodynamic cycles and one isodesmic reaction scheme have been employed.

\section{Method 1: Thermodynamic cycle 1}

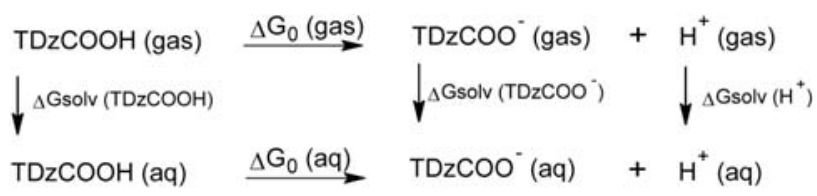

Scheme 2. Thermodynamic cycle (1) used for the $\mathrm{pK}_{\mathrm{a}}$ computation.

The value of $\mathrm{pK}_{\mathrm{a}}$ was calculated by means of the thermodynamic cycle presented in Figure 1. According to literature data, one of the main challenges in $\mathrm{pK}_{\mathrm{a}}$ computations consists in determining the appropriate value of the free energy of solvation of $\mathrm{H}^{+}$, as it is well known that an error of $1.36 \mathrm{kcal} / \mathrm{mol}$ leads to an 1 unit of $\mathrm{pK}_{\mathrm{a}}$ error. $^{22,24}$ The experimental data range within -254 and $-265.9 \mathrm{kcal} / \mathrm{mol},{ }^{21-24}$ but two of the most often used values are $-264.0 \mathrm{kcal} / \mathrm{mol}^{24}$ and $-265.9 \mathrm{kcal} / \mathrm{mol},{ }^{22}$ respec- tively. Within the present study, the values of -265.9 $\mathrm{kcal} / \mathrm{mol}$ (solvation) and $-6.28 \mathrm{kcal} / \mathrm{mol}$ (gas-phase) of the free energy of $\mathrm{H}^{+}$were considered. Also, the correction to the gas-phase free energy of the deprotonating reaction (RTln24.46, representing $1.895 \mathrm{kcal} / \mathrm{mol}$ ) was added. The correction factor is required for transforming the gas-phase free energy of the deprotonation reaction, computed to a reference state of 1 atm, in a value computed for a reference state of $1 \mathrm{M}$ (specific to the aqueous phase computations).

\section{Method 2: Thermodymanic cycle 2}

The second thermodynamic cycle is based on the reaction with a water molecule, when the corresponding anion of the thiadiazole derivative, along with the hydronium ion, is obtained. This way, the source of errors consisting in the thermodynamic parameters of $\mathrm{H}^{+}$is avoided. Within the following computations, the accepted values of the $\Delta \mathrm{G}_{\text {sol }} \mathrm{H}_{3} \mathrm{O}^{+}$and $\Delta \mathrm{G}_{\text {sol }} \mathrm{H}_{2} \mathrm{O}$ were considered -110.3 $\mathrm{kcal} / \mathrm{mol}$ and $-6.32 \mathrm{kcal} / \mathrm{mol}$, respectively.

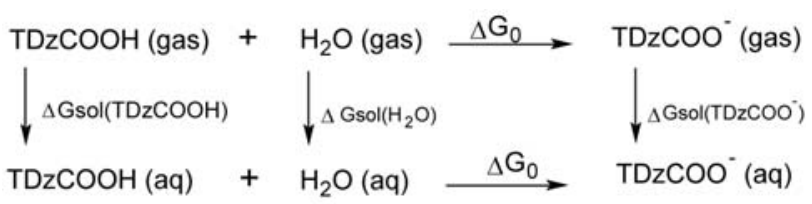

Scheme 3. Thermodynamic cycle (2) used for the $\mathrm{pK}_{\mathrm{a}}$ computation.

The equations that were used for the computation of $\mathrm{pK}_{\mathrm{a}}$ are the following:

$$
p K a=\frac{\Delta G a q}{R T \ln 10}
$$

where:

$$
\begin{aligned}
& \Delta G_{a q}=\Delta G_{g a s}+\Delta \Delta G_{\text {sol }} \\
& \Delta G_{g a s}=G_{g a s}(\text { products })-G_{g a s}(\text { reagents }) \\
& \left.\Delta \Delta G_{s o l}=\Delta G_{\text {sol }}(\text { products })-\Delta G_{\text {sol }} \text { (reagents }\right)
\end{aligned}
$$

Method 3: Isodesmic reaction scheme with thioglycolate

The isodesmic reactions are characterized by the conservation of the type of broken/formed bonds. Namazian and Heidary ${ }^{25}$ proposed an isodesmic reaction sche-

\begin{tabular}{llll}
$\mathrm{TDzCOOH}+\mathrm{HSCH}_{2} \mathrm{COO}^{-}$ & $\longrightarrow \mathrm{TDzCOO}^{-}+\mathrm{HSCH}_{2} \mathrm{COOH}$ \\
$\mathrm{HSCH}_{2} \mathrm{COOH}+\mathrm{H}_{2} \mathrm{O}$ & $\longrightarrow \mathrm{HSCH}_{2} \mathrm{COO}^{-}+\mathrm{H}_{3} \mathrm{O}^{+}$ \\
\hline $\mathrm{TDzCOOH}+\mathrm{H}_{2} \mathrm{O}$ & $\longrightarrow \mathrm{TDzCOO}^{-}+\mathrm{H}_{3} \mathrm{O}^{+}$
\end{tabular}

Scheme 4. Isodesmic reactions used for $\mathrm{pK}_{\mathrm{a}}$ computations 
me with acetate/acetic acid for the computation of $\mathrm{pK}_{\mathrm{a}}$ for a number of carboxylic acids with similar structure. In this regard, the thioglycolate ion and the thioglycolic acid were chosen as references for the $\mathrm{pK}_{\mathrm{a}}$ computation of the 2mercapto-1,3,4-thiadiazol-5-yl thioacetic acid.

\section{Experimental}

The geometric optimization of compounds Ia and Ib and their corresponding anions has been performed at B3LYP/6-311+G(d,p) level of theory. Vibrational analysis, carried out at the same level of theory, showed that no imaginary frequency was obtained. In order to quantify the effects of the aqueous environment, two solvation models -conductor-like polarizable continuum model (CPCM) and integral equation formalism polarizable continuum model (IEFPCM - with the solute characterized by the electronic density) - have been employed. ${ }^{26}$ The geometric optimization of the two tautomers (and of the corresponding anions) in aqueous environment have been also performed at B3LYP/6-311+G(d,p) level of theory, using both CPCM and IEFPCM solvation models. Geometry optimizations, frequency computations, thermochemistry data and reactivity indices (the condensed Fukui functions ${ }^{27}$ ) have been performed using the Gaussian 09W package. ${ }^{28}$ Also, for the NICS(0) and NICS(1) computations (NICS - Nucleus-Independent Chemical Shift), the GIAO (Gauge Independent Atomic Orbitals) approach within Gaussian 09W program has been employed. For the experimental determination of $\mathrm{K}_{\mathrm{a}}$ values, conductometric and potentiometric titrations have been performed using a MM 41 Crison multimeter, fitted with a conductivity cell and a glass electrode. For the determination of the equivalence points of potentiometric titration and for the calculation of $\mathrm{K}_{\mathrm{a} 1}$ and $\mathrm{K}_{\mathrm{a} 2}$ values, software applications developed by the authors (I. Julean and C. Muntean) have been used.

\section{Results and Discussions}

\section{1. Theoretical Calculation of pKa}

First ionization stage of 2-(5-mercapto-1,3,4-thiadiazol-2-ylthio)acetic acid consists in the removal of the $\mathrm{H}$ atom from the carboxyl group (reactions (1) and (3), respectively). The reaction is very similar for both tautomeric forms, leading to the obtaining of the thioacetate anion. Instead, significant differences appear during the second ionization stage, that involves $\mathrm{H}^{+}$removal from the $-\mathrm{SH}$ group (tautomer Ia) and the $\mathrm{H}^{+}$removal of the $-\mathrm{NH}$ group, a (tautomer Ib). One can approximate that a more "acidic" character is expected for the proton removal from the - $\mathrm{SH}$ group, which is directly bonded to the aromatic skeleton of 1,3,4-thiadiazole. In the case of the second ionization stage of the thione tautomer Ib, the hydrogen atom that has to be removed belongs to a secondary amino group (also, the cyclic delocalization of the electrons within the heterocyclic ring is affected).<smiles>O=C(O)Cc1nnc(S)s1</smiles>

la<smiles>O=C([O-])Cc1nnc(S)s1</smiles>

Ila

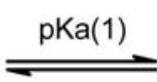<smiles>[O-]CCSc1nnc(S)s1</smiles>

Ila

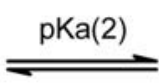<smiles>[O-]C=C[SeH]c1nnc(S)s1</smiles>

IIla

Scheme 5. The heterocyclic species involved in the first and second ionization of the thiol tautomer (Ia) of the 2-(5-mercapto-1,3,4-thiadiazol-2ylthio)acetic acid.<smiles>O=C(O)Cc1n[nH]c(=S)s1</smiles>

$\mathrm{lb}$<smiles>O=C([O-])c1n[nH]c(=S)s1</smiles>

$\mathrm{Ilb}$

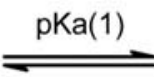<smiles>[O-]C=C1CCCCC1</smiles><smiles>[124OH]</smiles><smiles>Cn1nc([SeH]CC(=O)[O-])sc1=S</smiles>

Scheme 6. The heterocyclic species involved in the first and second ionization of the thione tautomer (Ib) of the 2-(5-mercapto-1,3,4-thiadiazol-2ylthio)acetic acid. 
The experimental results (see detailed information in Appendix) are presented in Table 1 and show a $3^{\text {rd }}$ order difference between the $\mathrm{K}_{\mathrm{a}}$ values (and, corresponding, $3 \mathrm{p}$ $\mathrm{K}_{\mathrm{a}}$ units) that were obtained for the two stages of the ionization process.

Table 1. Experimental values of $\mathrm{K}_{\mathrm{a}}$ and $\mathrm{pK}_{\mathrm{a}}$, determined for the first and second ionization stages of compound $\mathbf{I}$

\begin{tabular}{lcc}
\hline Compound & $\mathbf{K}_{\mathbf{a} 1}\left(\mathbf{p K}_{\mathbf{a 1}}\right)$ & $\mathbf{K}_{\mathbf{a} 2}\left(\mathbf{p K}_{\mathbf{a} 2}\right)$ \\
\hline $\mathbf{I}\left(\mathrm{C}_{4} \mathrm{H}_{4} \mathrm{~S}_{3} \mathrm{~N}_{2} \mathrm{O}_{2}\right)$ & $8.72 \cdot 10^{-3}(2.06)$ & $8.632 \cdot 10^{-6}(5.06)$ \\
\hline
\end{tabular}

The theoretical computations of $\mathrm{pK}_{\mathrm{a}}$ values allow the evaluation of the acid character of both tautomeric forms. Similarities with the experimental results will be used for the prediction of the dominant tautomer in aqueous solution).

Several conclusions can be drawn regarding the results presented in Table 2 and Table $3 ; \mathrm{pK}_{\mathrm{a} 1}$ values are very similar, regardless of the chosen method of computation. As expected, loosing the $\mathrm{H}$ atom of the carboxyl group (namely, the $\mathrm{pK}_{\mathrm{a} 1}$ value) is only slightly influenced from the thiol-thione tautomerism. The computed values show a difference of $0.65 \mathrm{pK}_{\mathrm{a}}$ units between the two tautomers, the more acidic being the thione form (Ib). Significant differences appear between the $\mathrm{pK}_{\mathrm{a} 2} \mathrm{va}-$ lues (almost $7 \mathrm{pK}_{\mathrm{a}}$ units is the difference between the thiol and thione tautomers). These results lead to the conclusion that, in aqueous solution, the dominant tautomer is Ia (the thiol form of the 2-(5-mercapto-1,3,4-thiadiazol-2-ylthio)acetic acid). The results presented in Table 2 show a $\Delta \mathrm{pK}_{\mathrm{a}}$ value around 3 , in good correlation with the experimental one. The results seem to illustrate the Gustafson's paradox: the most acidic tautomer is also the less abundant. ${ }^{5}$

As regards the accuracy of the results, it is obvious that the theoretical calculations of $\mathrm{pK}_{\mathrm{a}}$, regardless the chosen method, overestimate the $\mathrm{pK}_{\mathrm{a}}$ values. A possible ex- planation for the lower values of experimental $\mathrm{pK}_{\mathrm{a}}$ (when compared to the calculated ones) can be attributed to the undervaluing of the energies of the compounds when carrying PCM computations. Among the three variants that were used for the estimation of $\mathrm{pK}_{\mathrm{a}}$, differences appear only for the $\mathrm{pK}_{\mathrm{a} 2}$ values computed by means of the first thermodynamic cycle. As the $\mathrm{pK}_{\mathrm{a} 1}$ calculations (by means of all of the three methods) led to insignificant differences among the obtained values, it may be assumed that the underestimation of the $\mathrm{pK}_{\mathrm{a} 2}$ value, when using the first thermodynamic cycle, cannot be caused by the free energy of solvation of $\mathrm{H}^{+}$(considered $-265.9 \mathrm{kcal} / \mathrm{mol}$ within the present study).

\section{2. Similarities and Differences Between the Thiol-thione Tautomers Ia and Ib}

\section{2. 1. Aromatic Character of the Thiol- and Thione- Derivatives of the 2-(5-mercapto- 1,3,4-thiadiazol-2-yl-thio)acetic acid}

The magnetic criterion was chosen in order to evaluate the aromaticity of the two tautomers. In this regard, NICS(0) and NICS(1) computations were performed; the results are presented in Table 4.

Table 4. NICS(0) and NICS(1) values, computed at B3LYP/6$311+\mathrm{G}(\mathrm{d}, \mathrm{p})$ level of theory

\begin{tabular}{lcc}
\hline $\mathbf{C}_{\mathbf{4}} \mathbf{H}_{\mathbf{4}} \mathbf{S}_{\mathbf{3}} \mathbf{N}_{\mathbf{2}} \mathbf{O}_{\mathbf{2}}$ & $\mathbf{N I C S}(\mathbf{0})(\mathbf{p p m})$ & $\mathbf{N I C S}(\mathbf{1})(\mathbf{p p m})$ \\
\hline Tautomer Ia & -10.156 & -8.994 \\
Tautomer Ib & -7.310 & -5.194 \\
\hline
\end{tabular}

The results confirm that the thiol form of the 2-(5mercapto-1,3,4-thiadiazol-2-ylthio)acetic acid is more aromatic than the thione one; given that in the case of the thione tautomer, formation of the exocyclic $\mathrm{C}=\mathrm{S}$ bond disrupts the $\pi$-electron conjugation and leads to a decrease of the aromatic character.

Table 2. Theoretical $\mathrm{pK}_{\mathrm{a}}$ values calculated for the two ionization stages of the thiol tautomer (Ia)

\begin{tabular}{lcccccc}
\hline $\mathbf{C}_{\mathbf{4}} \mathbf{H}_{\mathbf{4}} \mathbf{S}_{\mathbf{3}} \mathbf{N}_{\mathbf{2}} \mathbf{O}_{\mathbf{2}}$ & \multicolumn{2}{c}{$\mathbf{p K _ { \mathrm { a } 1 }}$} & \multicolumn{2}{c}{$\mathbf{p K}_{\mathbf{a} 2}$} & \multicolumn{2}{c}{$\Delta \mathbf{p K}_{\mathbf{a}}=\mathbf{p K}_{\mathbf{a}(2)}-\mathbf{p K} \mathbf{K}_{\mathbf{a}(\mathbf{1})}$} \\
\hline Ia & IEFPCM & CPCM & IEFPCM & CPCM & IEFPCM & CPCM \\
Method 1 & 4.63 & 4.63 & 6.08 & 6.12 & 1.45 & 1.49 \\
Method 2 & 4.64 & 4.64 & 7.82 & 7.80 & 3.18 & 3.16 \\
Method 3 & 4.63 & 4.56 & 7.82 & 7.62 & 3.26 & 3.06 \\
\hline
\end{tabular}

Table 3. Theoretical $\mathrm{pK}_{\mathrm{a}}$ values calculated for the two ionization stages of the thiol tautomer (Ib)

\begin{tabular}{lcccccc}
\hline $\mathbf{C}_{\mathbf{4}} \mathbf{H}_{\mathbf{4}} \mathbf{S}_{\mathbf{3}} \mathbf{N}_{\mathbf{2}} \mathbf{O}_{\mathbf{2}}$ & \multicolumn{2}{c}{$\mathbf{p K}_{\mathrm{a} 1}$} & \multicolumn{2}{c}{$\mathbf{p K}_{\mathbf{a} 2}$} & \multicolumn{2}{c}{$\Delta \mathbf{p K}_{\mathbf{a}}=\mathbf{p K}_{\mathbf{a}(2)}-\mathbf{p K} \mathbf{K}_{\mathbf{a}(\mathbf{1})}$} \\
\hline $\mathbf{I b}$ & IEFPCM & CPCM & IEFPCM & CPCM & IEFPCM & CPCM \\
Method 1 & 3.98 & 3.97 & 12.30 & 12.28 & 8.32 & 8.31 \\
Method 2 & 3.98 & 3.99 & 14.00 & 14.05 & 10.02 & 10.06 \\
Method 3 & 3.94 & 3.86 & 13.99 & 13.80 & 10.05 & 9.94 \\
\hline
\end{tabular}

Pop et al.: Theoretical Considerations Regarding ... 
In addition to the magnetic index of aromaticity (NICS), the global stability of the six species involved in the ionization process (the two tautomers Ia and Ib and their corresponding monoanions and dianions) was evaluated. As well as in the case of other aromatic compounds, HOMO-LUMO gap computation represents an useful tool for comparisons among the stability of various species. ${ }^{29}$

Table 5. HOMO-LUMO gap of the Ia-IIIa and Ib-IIIb species (B3LYP/6311+G(d,p))

\begin{tabular}{cccc}
\hline & Ia & IIa & IIIa \\
HOMO-LUMO gap & 5.11 & 3.38 & 4.26 \\
$(\mathrm{eV})$ & Ib & IIb & IIIb \\
& 4.59 & 3.21 & 4.26 \\
\hline
\end{tabular}

According to the results presented in Table 5, the most stable specie is the tautomer Ia, whereas at the opposite side the monoanions IIa and IIb are found. The identic value obtained for the dianionic species IIIa and IIIb suggests that a delocalization of both the negative charge and the double bond appears among the N-C-S atoms, leading to the same specie (see Scheme 7).

\section{2. 2. NBO (Natural Bond Orbitals) Analysis}

The evaluation of the donor-acceptor interactions and their energetic contributions to the stability of the compounds is performed by means of the $2^{\text {nd }}$ order perturbation theory within NBO analysis. The stabilization energy E2, as difference between the localized-delocalized structures, is reported in tables below:

The results presented in Table 6 and Table 7 emphasize the differences among the thione and thiol form (namely between the neutral and monoanionic species, Ia-Ib and IIa-IIb). The lone pair of the nitrogen atom N4 has an exclusive $p$ character in the thione form, leading to stronger stabilization interactions. Regarding the $\mathrm{S} 6$ atom hybridization, it results that the content in $\mathrm{s}$ and $\mathrm{p}$ orbitals is changing when transition to the thiol to the thione form occurs. The dianionic species IIIa-IIIb are characterized by the same hybridization -as obtained for the thiol tautomer- for N4, while S6 has the same character as in the case of the thione tautomer, leading to the structure of the mesomeric form III. The specific donor-acceptor interactions of the $5 \mathrm{SH}-$ and $5 \mathrm{~S}$ - tautomers are preserved within the dianionic form III.<smiles></smiles>

IIIb

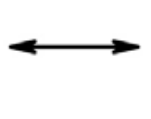

Scheme 7. Mesomeric species IIIa and IIIb.<smiles>O=C([O-])CSc1nnc(S)s1</smiles>

IIIa<smiles>O=C([O-])CC[SeH2]c1nnc(S)s1</smiles>

III

Table 6. NBO analysis of the $6 \mathrm{SH}$ tautomer

\begin{tabular}{llcc}
\hline Thiol tautomer & LP N3 hybridization & Donor-acceptor interactions & E2 (kJ/mol) \\
\hline Ia & $36.34 \% \mathrm{~s}, 63.54 \% \mathrm{p}$ & LP N4 $\leftrightarrow \sigma^{*}$ C5-S6 & 14.58 \\
IIa & $35.76 \% \mathrm{~s}, 64.13 \% \mathrm{p}$ & LP N4 $\leftrightarrow \sigma^{*}$ C5-S6 & 14.54 \\
IIIa & $36.43 \% \mathrm{~s}, 63.52 \% \mathrm{p}$ & LP N4 $\leftrightarrow \sigma^{*}$ C5-S6 & 14.79 \\
& LP S6 hybridization & & 24.52 \\
Ia & $68.91 \% \mathrm{~s}, 31.07 \% \mathrm{p}$ & LP S6 $\leftrightarrow \pi^{*}$ C5-N4 & 21.56 \\
IIa & $68.25 \% \mathrm{~s}, 31.73 \% \mathrm{p}$ & LP S6 $\leftrightarrow \pi^{*}$ C5-N4 & 39.22 \\
IIIa & $81.17 \% \mathrm{~s}, 18.82 \% \mathrm{p}$ & LP S6 $\leftrightarrow \pi^{*}$ C5-N4 & \\
\hline
\end{tabular}

Table 7. NBO analysis of the $6 \mathrm{~S}$ tautomer

\begin{tabular}{llcc}
\hline Thione tautomer & LP N4 hybridization & Donor-acceptor interactions & E2 (kJ/mol) \\
\hline Ib & $99.99 \% \mathrm{p}$ & LP N4 $\leftrightarrow \sigma^{*}$ C5-S6 & 74.37 \\
& & LP N4 $\leftrightarrow \pi^{*}$ C2-N3 & 32.36 \\
$\mathrm{IIb}$ & $99.99 \% \mathrm{p}$ & LP N4 $\leftrightarrow \sigma^{*}$ C5-S6 & 80.22 \\
& & LP N4 $\leftrightarrow \pi^{*}$ C2-N3 & 28.47 \\
$\mathrm{IIIb}$ & $36.40 \% \mathrm{~s}, 63.50 \% \mathrm{p}$ & LP N4 $\leftrightarrow \sigma^{*}$ C5-S6 & 14.91 \\
& LP S6 hybridization & & 11.94 \\
$\mathrm{Ib}$ & $81.39 \% \mathrm{~s}, 18.59 \% \mathrm{p}$ & LP S6 $\leftrightarrow \pi^{*} \mathrm{C} 5-\mathrm{N} 4$ & 11.62 \\
$\mathrm{IIb}$ & $81.02 \% \mathrm{~s}, 18.95 \% \mathrm{p}$ & LP S6 $\leftrightarrow \pi^{*} \mathrm{C} 5-\mathrm{N} 4$ & 39.80 \\
$\mathrm{IIIb}$ & $81.17 \% \mathrm{~s}, 18.81 \% \mathrm{p}$ & LP S6 $\leftrightarrow \pi^{*} \mathrm{C} 5-\mathrm{N} 4$ & \\
\hline
\end{tabular}

Pop et al.: Theoretical Considerations Regarding ... 


\section{2. 3. Reactivity Indices}

Condensed Fukui functions have been computed for the N4, N3 and S6 heteroatoms, in order to assess their reactivity during a reaction with an electrophile. ${ }^{26}$

Table 8. Condensed Fukui functions computed for the 6SH tautomer (B3LYP/6-311+G(d,p))

\begin{tabular}{lccc}
\hline Atom & $\mathbf{f}^{-}(\mathbf{I a})$ & $\mathbf{f}^{-}(\mathbf{I I a})$ & $\mathbf{f}^{-}$(IIIa) \\
\hline N4 & 0.064 & 0.111 & 0.091 \\
N3 & 0.068 & 0.072 & 0.034 \\
S6 & 0.171 & 0.028 & 0.356 \\
\hline
\end{tabular}

Table 9. Condensed Fukui functions computed for the $6 \mathrm{~S}$ tautomer (B3LYP/6-311+G(d,p))

\begin{tabular}{lccc}
\hline Atom & $\mathbf{f}^{-}(\mathbf{I b})$ & $\mathbf{f}^{-}(\mathbf{I I b})$ & $\mathbf{f}^{-}(\mathbf{I I I b})$ \\
\hline N4 & 0.109 & 0.048 & 0.091 \\
N3 & 0.056 & 0.028 & 0.034 \\
S6 & 0.335 & 0.021 & 0.353 \\
\hline
\end{tabular}

The condensed Fukui functions computed for the neutral forms Ia and Ib show that the S6 atom has the largest electrophilic character (higher for the thione tautomer). The two $\mathrm{N}$ atoms of the thiadiazole heterocycle have similar reactivity in the case of the tautomer Ia (see Table 8 ); the reactivity difference between the two $\mathrm{N}$ atoms of the tautomer Ib is outlined by the almost double value obtained for the N4 atom. The S6 atoms within the monoanionic species present the lowest reactivity; the graphical presentation of the HOMO orbitals of the thioglycolate anions clearly shows that the highest electrophilic character appears at the thyoglycolate residue, not within the heterocyclic ring (see Appendix). The dianion III shows a similar reactivity of the S6 atom as in the case of the thione form, whereas the reactivity of the $\mathrm{N} 4$ atom is between (almost the mean value) the values of Fukui function $\mathrm{f}^{-}$of the $\mathrm{N} 4$ atom in the thiol and thione tautomers.

\section{Conclusions}

Theoretical evaluation of the $\mathrm{pK}_{\mathrm{a}}$ for the two ionization stages of 2-(5-mercapto-1,3,4-thiadiazol-2-ylthio) acetic acid (both tautomeric forms) have been performed, in order to predict the more stable tautomer in aqueous solution. Two solvation models, IEFPCM and CPCM, have led to similar results for the solvation free energies of all the species involved in the ionization process. Two thermodynamic cycles and one isodesmic reaction scheme have been used for the theoretical computation of $\mathrm{pK}_{\mathrm{a}}$. Compared with the experimental results, theoretical calculations tend to overestimate the $\mathrm{pK}_{\mathrm{a}}$ values; instead, the computed difference $\Delta \mathrm{pK}_{\mathrm{a}}$ has the same value for both theoretical and experimental results obtained for the thiol tautomer Ia. The results led to the conclusion that, in aqueous solution, the thiol form is the more stable tautomer. Also, NBO analysis for the 6SH and 6S tautomers has been carried out and the donor-acceptor interactions that lead to the stabilization of the compounds have been identified. The reactivity differences between the two tautomers are outlined by the values of the condensed Fukui functions, computed for the heteroatoms involved in the tautomeric equilibrium.

\section{References}

1. Y. Li, J. Genq, Y. Liu, S. Yu, G. Zhao, Chem. Med. Chem. 2013, 8(1), 27-41.

http://dx.doi.org/10.1002/cmdc.201200355

2. T. A. Farghaly, M. A. Abdallah, M. R. Abdel Aziz, Molecules 2012, 17, 14625-14636.

http://dx.doi.org/10.3390/molecules 171214625

3. V. Palomo, D. I. Perez, C. Perez, J. A. Morales-Garcia, I. Soteras, S. Alonso-Gil, A. Encinas, A. Castro, N. E. Campillo, A. Perez-Castillo, C. Gil, A. Martinez, J. Med. Chem. 2012, 55(4), 1645-1661. http://dx.doi.org/10.1021/jm201463v

4. D. I. Perez, M. Pistolozzi, V. Palomo, M. Redondo, C. Fortugno, C. Gil, G. Felix, A. Martinez, C. Bertucci, Eur. J. Pharm. Sci. 2012, 45(5), 677-684.

http://dx.doi.org/10.1016/j.ejps.2012.01.007

5. I. Alkorta, P. Goya, J. Elguero, S. P. Singh, Natl. Acad. Sci. Lett. 2007, 30, 139-159.

6. N. Tokay, C. Ogretir, Arkivoc 2008, xiv, 88-99. http://dx.doi.org/10.3998/ark.5550190.0009.e10

7. N. S. Babu, Am. J. Sci. J. 2013, 3(2), 137-150.

8. R. A. Jones, A. Whitmore, Arkivoc 2007, xi, 114-119.

9. M. D. Davari, H. Bahrami, Z. Z. Haghighi, M. Zahedi, J. Mol. Model. 2010, 16(5), 841-855. http://dx.doi.org/10.1007/s00894-009-0585-z

10. M. Karelson, U. Maran, Tetrahedron 1996, 52(34), 1132511328. http://dx.doi.org/10.1016/0040-4020(96)00659-X

11. X.-C. Wang, J. Nichols, M. Feyereisen, M. Gutowski, J. Boatz, A. D. J. Haymet, J. Simons, J. Phys. Chem. 1991, 95 , 10419-10424. http://dx.doi.org/10.1021/j100178a032

12. Y. Podolyan, L. Gorb, J. Leszczynski, Int. J. Mol. Sci. 2003, 4, 410-421. http://dx.doi.org/10.3390/i4070410

13. M. Hanus, M. Kabelac, J. Rejnic, F. Ryjacek, P. Hobza, J. Phys. Chem. B 2004, 108, 2087-2097. http://dx.doi.org/10.1021/jp036090m

14. P. J. Taylor, G. van der Zwan, L. Antonov, “Tautomerism: Introduction, history, and recent developments in experimental and theoretical methods" in Tautomerism: Methods and Theories, First Ed. (edited by L. Antonov), Wiley-VCH Verlag, 2014.

15. J. L. G. de Paz, J. Elguero, C. Foces-Foces, A. L. LlamasSaiz, F. Aguilar-Parrilla, O. Klein, H. H. Limbach, J. Chem. Soc. Perkin Trans. 1997, 2, 101-109. http://dx.doi.org/10.1039/a603035a

16. T. A. Farghaly, Z. A. Abdallah, Arkivoc 2008, xvii, 295-305. 
17. C. Ogretir, Y. Gulseven Sidir I. Sidir, E. Tasal, Turk. J. Chem. 2010, 34, 977-988.

18. M. M. Venter, V. N. Bercean, M. Ilici, S. Cîntã Pînzaru, Rev. Roum. Chim. 2007, 52(1-2), 75-79.

19. M. M. Venter, V. Chis, S. Cîntã Pînzaru, N. V. Bercean, M. Ilici, I. Haiduc, Studia Univ. Babes-Bolyai Chemia 2006, , LI(2), 65-70.

20. M. M. Venter, A. Pascui, V. Bercean, S. Cinta Pinzaru, Studia Univ. Babes-Bolyai, Chemia 2007, LII(1), 55-60.

21. G. da Silva, E. M. Kennedy, Z. Dlugogorski, J. Phys. Chem. A 2006, 110, 11371-11376. http://dx.doi.org/10.1021/jp0639243

22. K. S. Alongi, G. C. Shields, Annual Reports in Computational Chemistry 2010, 6, 113-138. http://dx.doi.org/10.1016/S1574-1400(10)06008-1

23. I. E. Charif, S. M. Mekelleche, D. Villemin, N. Mora-Diez, J. Molec. Struct. (THEOCHEM) 2007, 818, 1-6. http://dx.doi.org/10.1016/j.theochem.2007.04.037

24. M. W. Palascak, G. C. Shields, J. Phys. Chem. A 2004, 108, 3692-3694. http://dx.doi.org/10.1021/jp049914o

25. M. Namazian, H. Heidary, J. Mol. Struct. (THEOCHEM) 2003, 620, 257-263. http://dx.doi.org/10.1016/S0166-1280(02)00640-1

26. J. Tomasi, B. Mennucci, R. Cammi, Chem. Rev. 2005, 105, 2999-3093. http://dx.doi.org/10.1021/cr9904009
27. R. R. Contreras, P. Fuentealba, M. Gaban, P. Perez, Chem. Phys. Lett. 1999, 304, 405. http://dx.doi.org/10.1016/S0009-2614(99)00325-5

28. Gaussian 09, Revision D.01, M. J. Frisch, G. W. Trucks, H. B. Schlegel, G. E. Scuseria, M. A. Robb, J. R. Cheeseman, G. Scalmani, V. Barone, B. Mennucci, G. A. Petersson, H. Nakatsuji, M. Caricato, X. Li, H. P. Hratchian, A. F. Izmaylov, J. Bloino, G. Zheng, J. L. Sonnenberg, M. Hada, M. Ehara, K. Toyota, R. Fukuda, J. Hasegawa, M. Ishida, T. Nakajima, Y. Honda, O. Kitao, H. Nakai, T. Vreven, J. A. Montgomery, Jr., J. E. Peralta, F. Ogliaro, M. Bearpark, J. J. Heyd, E. Brothers, K. N. Kudin, V. N. Staroverov, T. Keith, R. Kobayashi, J. Normand, K. Raghavachari, A. Rendell, J. C. Burant, S. S. Iyengar, J. Tomasi, M. Cossi, N. Rega, J. M. Millam, M. Klene, J. E. Knox, J. B. Cross, V. Bakken, C. Adamo, J. Jaramillo, R. Gomperts, R. E. Stratmann, O. Yazyev, A. J. Austin, R. Cammi, C. Pomelli, J. W. Ochterski, R. L. Martin, K. Morokuma, V. G. Zakrzewski, G. A. Voth, P. Salvador, J. J. Dannenberg, S. Dapprich, A. D. Daniels, O. Farkas, J. B. Foresman, J. V. Ortiz, J. Cioslowski, and D. J. Fox, Gaussian, Inc., Wallingford CT, 2013.

29. J. Aihara, J. Phys. Chem. A 1999, 103 (37), 7487-7495. http://dx.doi.org/10.1021/jp990092i

\section{Povzetek}

Za 2-(5-merkapto-1,3,4-tiadiazol-2-iltio)ocetno kislino smo določili eksperimentalne in teoretične vrednosti konstant $\mathrm{K}_{\mathrm{a} 1}$ in $\mathrm{K}_{\mathrm{a} 2}$. Izračune $\mathrm{pK}_{\mathrm{a}}$ smo za dve tavtomerni obliki izvedli na B3LYP/6-311+G(d,p) nivoju. S primerjavo eksperimentalnih in izračunanih vrednosti smo določili najbolj stabilno tavtomero preiskovane kisline v vodni raztopini. Dodatno smo izvedli smo še DFT analize reaktivnosti, aromatskega značaja in populacije obeh tavtomer. 